\title{
Develerde Karkas ve Et Kalite Özellikleri
}

\section{Abdullah BÜLBÜL'(i), Atakan KOÇ*'(D)}

\section{' Aydın Adnan Menderes Üniversitesi, Ziraat Fakültesi Zootekni Bölümü, Aydın}

Öz: Ülkelerin fiziksel ve doğal koșulları yanında toplumların kültürel yapısı da yetiștirilecek hayvan türünü belirlemede etkilidir. Birçok çiftlik hayvanı türünün yetiștirilemediği alanlarda yetiștirilen devenin dünyadaki varlığı 2017 yılında 196I yılına göre 2.69 kat artmıșken, Afrika kıtasında artış 3.49 kattır. Dünyada, kanatlı, eșek ve keçi etinden sonra deve eti üretimi oransal olarak en fazla artıș gösteren ettir. Ülkelere göre değișmekle birlikte dünya genelinde develerde kasaplık güç oranı \%।I.3, yıllık kesilen deve sayısı 2.84 milyon baș, deve eti üretimi 630,210 tondur. Develerde karkas ağırlı̆ı kesim canlı ağırlığına bağlı olarak 125-400 kg, karkas randımanı ise \%47.7-61.5 arasında değișmektedir. Genç yașta kesildiğinde sığır eti ile benzer özellikler gösteren deve etinde kolesterol miktarı düșüktür.

Anahtar Kelimeler: et üretimi, kasaplık güç, karkas ağırlı̆̆ı, et kalitesi, biyoaktif bileșikler

\section{Carcass and Meat Quality Characteristics of Camel}

Abstract: Beside the physical and natural conditions of countries or regions, cultural structure of the societies have also effects on reared animal species. Camel can be reared in the regions in which main livestock species cannot be reared and the world camel population increased about 2.69fold from 196I to 2017, increase in Africa is 3.49-fold. Proportionately, camel meat production is the most increased meat in the world, after the poultry, ass and goat meat production. Slaughtering rate, as varies countries, in the camel population in the world is $11.3 \%$, the number of slaughtered camel is $2.84 \mathrm{~m}$ heads and camel meat production is 630,210 tons. Camel carcass weight, depending on the slaughtering weight, varies between 125 and $400 \mathrm{~kg}$, and dressing percentage varies from $47.5 \%$ to $61.5 \%$. The quality characteristics of camel meat, with low cholesterol content, are similar to beef quality characteristics, especially if they were slaughtered at a younger age.

Keywords: Meat production, slaughtering rate, carcass weight, meat quality, bioactive compounds

\section{GiRiș}

Artan dünya nüfusu ve dünya genelinde yetersiz beslenen insanlar düșünüldüğünde, hayvansal kaynaklı gıdaya olan talep her geçen gün artmaktadır. Dini inançlar, coğrafi ve iklim șartları ve ekonomik durum insanların tercihlerini etkilemede önemli rol oynamaktadır. FAO verilerine göre 2017 yılında dünyada üretilen toplam 332.5 milyon ton etin \%36.69'u kanatlı, \%36.06'sı domuz ve \%19.93'ü de sığırlardan sağlanırken (Șekil I) devegillerin et üretimine katkısı yalnızca \%0.2 dir (Anonim, 2018).

Dünyada değişik türlere ait et üretim miktarı, 000 ton (FAO, 2017)

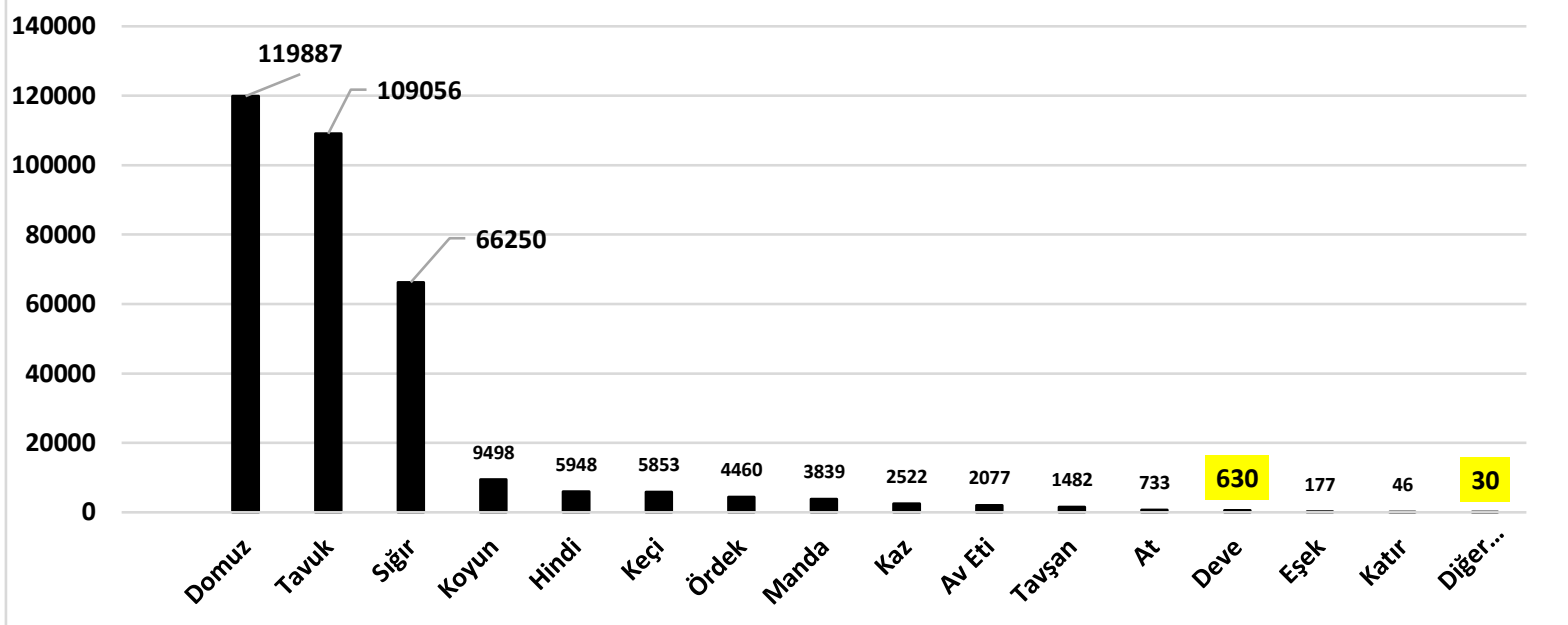

Șekil I. Dünyada değișik türlere ait et üretim miktarı (Anonim, 20I8)

Çok yönlü bir hayvan olan deve, süt, et, yün, tașımacılık, turizm, yarıș ve güreș gibi çok farklı amaçlar için yetiștirilmektedir (İnce ve Önal, 2017). Diğer evcil hayvanlarla karșılaștırıldığında klasik bir et kaynağı olarak kabul edilmemesine karșın, iri vücut yapısı ve yağsız et üretmesi önemli avantaj sağlamaktadır. Son yıllarda devenin
Sorumlu Yazar: akoc@adu.edu.tr Bu derleme makale II. Uluslararası Selçuk-Efes Devecilik Kültürü ve Deve Güreșleri Sempozyumunda Sözlü olarak sunulmuş ve özeti Özet Kitapçığında yayınlanmıștır.

Geliş Tarihi: 29 Mayıs 2018

Kabul Tarihi: 26 Aralık 2018 
anatomisi, fizyoloji ve hastalıklar gibi konularda bilimsel yayınlar azda olsa artarken, develerin karkas ve et kalite özelliklerinin çok az ilgi gördüğü, bu alanda yapılan çalıșma sayısının ise yeterli olmadığı da bir gerçektir. Dünyada 196I2017 yılları arasında kanatılar (tavuk, ördek ve hindi), eșek ve keçi etinden sonra en fazla artış 5.II kat ile deve eti üretiminde gerçekleșmiş (Anonim, 20l8), kesilen deve sayısı ve deve eti üretimine yönelik istatistiklerin yetersizliği üretimin bildirilenden çok daha yüksek olduğunu göstermektedir (Faye, 2014).

Develerde "kasaplık güç" oranı 2014 yılı verilerine göre Asya kıtası için \%।6.2 Afrika ve Avrupa için sırasıyla \%।0.4 ve \%9.8, dünya genelinde ise \%। I.3 dolayındadır (Anonim, 2017). Ülkelere göre önemli değișiklik göstermekle birlikte özellikle Mısır, Kuveyt ve Suudi Arabistan'da kasaplık güç oranının \%70'lerin üzerinde (Șekil 2) bulunması, bu ülkelerin önemli miktarda canlı deve ithal ederek kesim yaptığını göstermektedir (Bülbül, 20I7). Kesilen deve sayısının 2017 yılı FAO verilerine göre 2.84 milyon baș olduğu ve 630,210 ton deve eti üretildiği düșünüldüğünde, develerde ortalama karkas ağırlığı $221.7 \mathrm{~kg}$ olarak hesaplanabilir. Dünya genelinde üretilen deve etinin \%66.63'ü Afrika'da, \%33.34'ü Asya'da, \%0.03'ü de Avrupa'da üretilmiștir (Anonim, 2018). Devenin toplam et üretimine katkısı düșük olmasına karșın, son yıllarda sığır, koyun, manda ve at etinden daha fazla büyüme oranına sahip olmuș, 1961-2017 arasında Afrika kıtasında 6.0 kat, Asya kıtasında 3.9 kat artmıștır (Anonim, 2018).

Devede kasaplık güç oranının ülkelere göre değişimi (\%; FAO, 2014)

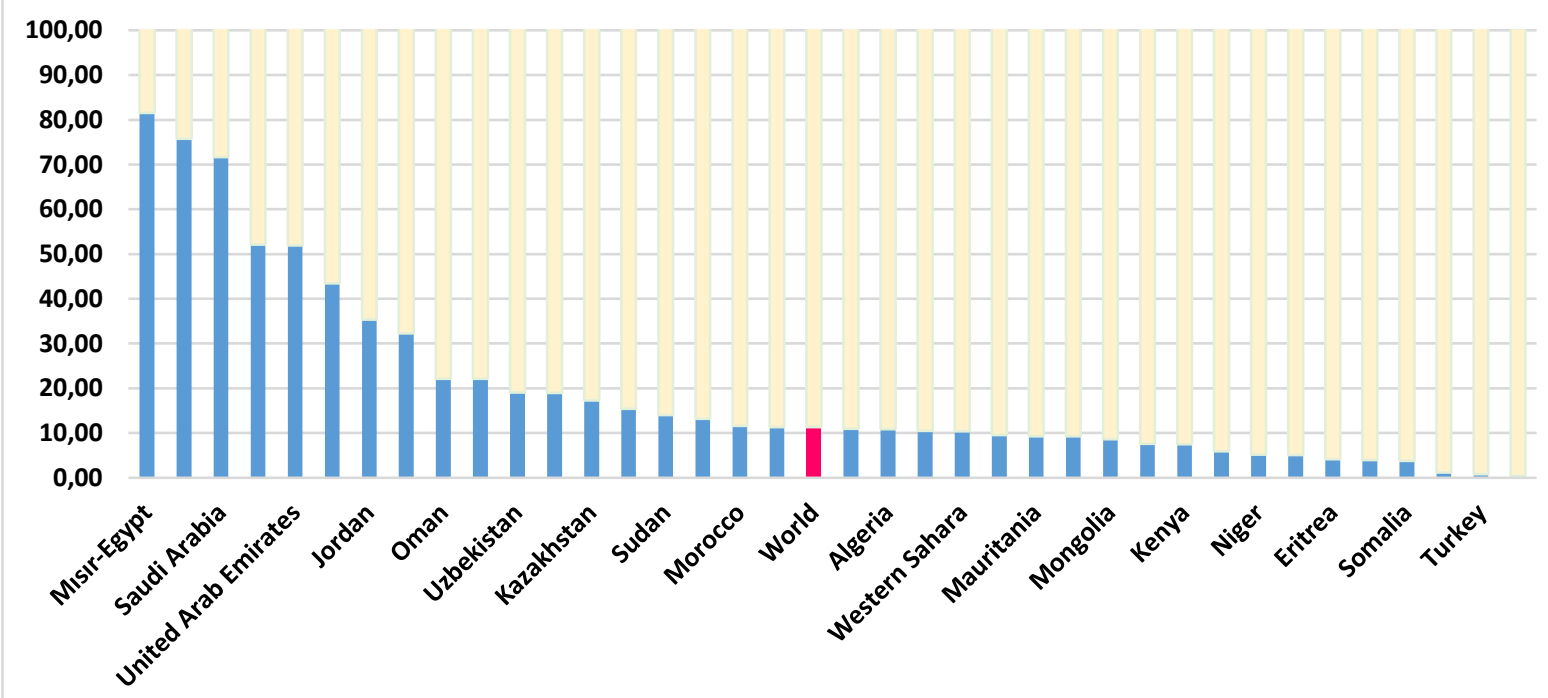

Șekil 2. Devede kasaplık güç oranının ülkelere göre değișimi (Anonim, 20I7)

Dünya genelinde entansif deve besi ișletmeleri henüz yaygınlașmamıș, deve eti üretimi süt üretiminin bir yan ürünü iken, gelecekte gelișim gösterecek alanlardan birisinin de deve eti pazarının olacağı ifade edilmiștir (Faye, 2014). Diğer taraftan 36 aylıktan küçük deve etine talebin yüksek, karkas derecelendirmenin ise subjektif unsurlardan objektif unsurlara kaydığı belirtilmiștir (Swatland, 20I4).

\section{Develerde Kesim ve Karkas Özellikleri}

Deve eti üretiminin az, kesim yapan tesisler sınırlı, deve kesiminin de oldukça zor olduğu belirtilmelidir. Develerin çoğu insana alıșık olmasına rağmen, yükleme, nakil, kesim öncesi ve sonrası ișlemler gibi tüm yöntemler deneyim gerektirmektedir.

Develer nakil sonrasında sakin bir șekilde mezbahaya yönlendirilmeli ve kesimden önce et kalitesini etkileyeceğinden stres azaltılıp dinlenmesi sağlanmalıdır. Kesim için tașınmasından 12-24 saat önce develere verilen yemin kesilmesi, rumendeki potansiyel patojenlerin ve dıșkı kaynaklı bakterilerinin çoğalmasını engelleyecektir, ancak, su içmesine imkan tanınması kesimde kanamanın artmasını sağlayarak parlak, renkli, yağsız karkas elde edilmesine ve derinin yüzülmesine katkı sağlayacağı bildirilmektedir. Develerde kesim için en yaygın yöntemin çömeltildikten sonra diz ekleminden ön bacakları birbirine bağlayıp bașın bir tarafa yatırılarak kesilmesi olduğu belirtilmiștir (Kadim et al., 2014).

Geleneksel olarak, kesim öncesinde tek hörgüçlü develere bayıltma ișlemi uygulanmaz. Ancak, büyükbaș hayvanlarda kesim öncesinde kullanılan mekanik ve elektriksel bayıltma yöntemleri develerde de kullanılabilmektedir. Kesilecek hayvanlara bayıltılma uygulanmadığında kesim esnasında acı, korku, panik ve kanın akciğerlere kaçması gibi komplikasyonlar görülebilmektedir (Kadim et al., 20l4).

Diğer türlerde olduğu gibi deve karkas özellikleri de yașa, cinsiyete, ırka, sağlık ve besleme durumuna göre değișmektedir. Deve eti kısmen sığır etinin tadına ve 
besleyici değerine benzer olmasının yanında yağ ve $E$ Vitamini oranı düșüktür (Swatland, 20l4).

Diğer çiftlik hayvanı türlerine göre deve karkası üzerinde yapılan çalıșmalar oldukça sınırlıdır. Tek hörgüçlü develerin karkas konformasyonu diğer türlerden bazı açılardan farklılık göstermektedir (Kadim ve Mahgoub, 20l4). Sırtındaki hörgüç dıșında, butta bulunan kasların sınırlı olması da deve karkasının diğer et hayvanlarından olan önemli bir farklılığıdır. Toplam satılabilir et (biftek, göğüs, fileto, yağsız et) iyi konformasyona sahip deve karkaslarında daha yüksektir.

Tek hörgüçlü (Dromedary) develerde karkas ağırlığının 68.0 kg ile 393.7 kg arasında değiștiği, İran develerinde karkas ağırlığının 300-400 kg gibi oldukça yüksek olduğu ifade edilmișken (Kadim et al., 2008), develerde karkas ağırlığının I25-400 kg, 15-50 aylık yașlar arasındaki erkek develerde I50-343 kg arasında değiștiği(Kadim ve Mahgoub, 20l4), Tunus'ta ise kasaplık develerin $250 \mathrm{~kg}$ canlı ağırlığa ulașana kadar büyütüldükten sonra kesildiği (Faye, 2014) bildirilmiștir. Kıtalara göre kesilen deve sayısı ve üretilen deve eti rakamları üzerinden deve karkas ağırlığının Asya, Afrika ve Avrupa'da sırasıyla $202.3 \mathrm{~kg}, 23 \mathrm{I} . \mathrm{l} \mathrm{kg}$ ve $241.4 \mathrm{~kg}$ olduğu hesaplanabilir (Anonim, 2017).

Cinsiyet, kondisyon ve ırka göre değișim gösteren karkas randımanı Dromedarlarda \%47.4 ile \%63.8 arasında, erkeklerde dișilerden daha yüksek, esas olarak yağdan olușan hörgücün karkas ağırlığına oranının ise \%8.6 dolayında olduğu ifade edilmiștir (Kadim et al., 2008),

Boyutu nedeniyle, sığır karkasına benzer olarak, deve karkasları da hızı soğutulması için ortadan ikiye ayrılır ve 24॰C sıcaklıkta 12-24 saat bekletildikten sonra depolanabilir ya da parçalama ișlemine geçilir. Deve karkası sağ ve sol yarısı 12. kaburga ve I. bel omuru arasından veya 8 . ve 9. kaburgalar arasından tekrar ikiye ayrıldıktan sonra parçalanır. Arka çeyrek, ön çeyreğe göre daha büyük ve yumușak kaslara sahip olduğu için değeri daha yüksektir (Kadim et al., 20l4).

Sığırla karșılaștırıldığında deri ve ayakların ağırlığının canlı ağırlığa oranı daha yüksek, baș ağırlığının oranı daha düșük olduğu belirtilerek, develerde karaciğerin sığırlardan daha ağır olduğu ifade edilmiștir (Kadim et al., 20l4). Ayrıca sığır, koyun ve keçilerle karșılaștırıldığında, develerin böbrek ağırlığının daha yüksek, sindirim kanalı ve baș ağırlığının daha az olduğu, develerde böbreklerin vücut ağırlığına oranının sığırın iki katı, koyunun ise dört katı kadar olmasının kurak alanlara adaptasyonunun önemli bir göstergesi olduğu bildirilmiștir. Develerde yenilebilir yan ürünler olan yürek, karaciğer, akciğer, ișkembe, dalak, böbrek, dil ve beyinde yağ oranı düșük, protein, B Vitaminleri, demir, çinko ve bakır bakımından ise zengindir (Kadim ve ark., 20I4).

Diğer çiftlik hayvanı türlerinde olduğu gibi develerde standart bir karkas parçalama yöntemi bulunmamaktadır. Genel olarak karkas ortadan ikiye ayrıldıktan sonra, tekrar ikiye bölünerek parçalanmaktadır. Karkasın ön çeyreği beș parçaya (boyun, omuz ya da kürek eti, döș, kaburga ve karın), arka çeyreği ise üç parçaya (bel ya da fileto, böğür ya da pençata ve but) ayrılmaktadır. Deve karkaslarında ön çeyrek arka çeyreğe göre daha ağırdır ve bu farklıılı boyun ve hörgüçten kaynaklanmaktadır (Kadim et al., 2008). Bu farklılıkta diğer çiftlik hayvanı türlerine göre develerde
BÜLBÜL A, KOÇ A

butların daha az gelișmiș olmasının da önemli payı bulunmaktadır.

Karkas Kompozisyonu: Develerde karkas kompozisyonu yaș, cinsiyet, ırk ve besleme durumundan önemli derecede etkilenmektedir. Diğer çiftlik hayvanı türlerine benzer olarak, yașlı develer gençlerden, diși develer de erkeklerden daha fazla karkas yağına sahiptir. Beslenme durumuna göre önemli değișim göstermekle birlikte, deve etinin yağsız olması esas olarak kas içi ve kaslar arası yağ oranının daha düșük olmasından kaynaklanmaktadır. Deve karkasındaki yağın en büyük kısmı hörgüçte (\%30), sonra böbrek yatağında (\%II) bulunur. Karın kaslarını kaplayan ve böbrek yatağına doğru uzanan karın zeminindeki yağ tabakası çölde sıcak kumdan yayılan sıcaklığa karșı izolasyon sağlamaktadır (Bülbül, 2017).

Deve karkaslarında et oranının \%56, kemik oranının \%19, yağ oranının \%4 olduğu belirtilmiștir (Kadim et al., 20।4). Sığır karkası ile karșılaștırıldığında, deve karkasında kemik oranı daha yüksek, et:kemik oranı daha düșüktür. Develerde, yenilebilir bir doku olmasa da kas ve yağ gibi karkastaki diğer yenilebilir dokuların oranlarını etkilediğinden, kemik oranı karkas kalitesinin değerlendirilmesinde önemli bir ölçüttür (Bülbül, 20I7). Sudan develerinde et:kemik oranının 3.0 dolayında olduğu, vücutta kasların dağılımının anatomik bölgeye göre değiștiği, karkastaki en yüksek kas oranının kaburga, omurga kemiği, but, ön bacak ve boyunda bulunduğu belirtilmiștir (Kadim et al., 2008).

Et kompozisyonu: Deve eti kompozisyonu ırka, yașa, cinsiyete, kondisyona ve karkas bölgesine göre değișiklik gösterir. Deve eti \%65.70-78.85 oranında su (Bekhit ve Farouk, 2014) ile kurak ve yarı kurak alanlarda yașayan insanlar için iyi bir besin kaynağı olarak \%20-23 oranında protein içerir (Kadim et al., 2008). Deve etinde bulunan yağ oranı yașla birlikte artarak göz kasında \%।0’lar düzeyine çıkarken, mineral madde oranı \%І.I-I.5 arasında değișmektedir. Deve eti diğer kırmızı etler gibi yüksek miktarda K, P, Na, Mg ve Ca içerir. Deve etinde $\mathrm{Ca}$ oranının sığır etinden daha yüksek olduğu bildirilmiștir (Kadim et al., 2008).

Deve eti yağ içeriği yaș ve besleme durumuna göre değișmekle birlikte, dana ve kuzu etine göre daha düșük kolesterol içerdiği bildirilmiş (Kadim et al., 2008), ancak yüksek oranda değișim gösteren kolesterol oranının besleme, yaș, cinsiyet ve analiz yöntemine göre önemli değișim gösterdiği vurgulanmıștır (Kadim et al., 2008; Bekhit ve Farouk, 2014). Deve etinin yağ ve kolesterol içeriğinin düșük olması, diğer çiftlik hayvanı etleri ile karșılaștırıldığında daha sağlıklı bir gıda olduğu șeklinde değerlendirilebilir.

Deve etindeki yağ asidi kompozisyonu üzerine yapılmıș çalıșmaların çok olmadığı gibi diğer türlerin yağ asidi kompozisyonu ile karșılaștıran çalıșmalar da bulunmamaktadır.

Etteki yağ asidi kompozisyonu hayvanın tükettiği rasyondan önemli derecede etkilenmektedir. Deve etinde bulunan ana doymuș, tekli doymamış ve çoklu doymamış yağ asitleri sırasıyla C16:0, CI8:I ve C18:2 olduğu bildirilerek, deve etindeki toplam doymuș yağ asidi oranı bakımından 
bir fikir birliği varken (\%5I.5-53), tekli (\%29.9-4I.4) ve çoklu (\%5.6-18.6) doymamıș yağ asitleri bakımından araștırmalar arasında önemli farklılık bulunmaktadır (Bekhit ve Farouk, 2014).

Diğer taraftan develerde \%64.2-84.8 oranında yağ içeren hörgücün önemli miktarda (\%63) doymuș yağ asidi içerdiği ve en fazla bulunan yağ asitlerinin Palmiktik asit $(\mathrm{Cl6:0})$, Stearik asit (CI8:I) ve Oleik asit (CI8:2) olduğu ifade edilmiștir. Deve eti yağ asidi kompozisyonunun hayvanın yașından etkilendiği de belirtilerek en fazla doymamıș yağ asidi ve en az doymuș yağ asidinin bir yașından küçük hayvanların etinde bulunduğu belirtilmiștir (Bekhit ve Farouk, 2014). Ayrıca, deve etindeki linoleik asit metabolitlerinin linolenik asit metabolitlerine oranının 10.9 gibi dana, kuzu ve oğlak etine (2.0, 2.4 ve 2.8$)$ göre oldukça yüksek olduğunu bildirilmiștir (Kadim et al., 2008).

Deve etinin histidin, tryptofan, valin, lösin ve isolösin gibi bazı amino asitler (aa) bakımından düșük, lizin dıșındaki diğer aa bakımından kuzu etine benzer özellik gösterdiği belirtilmiștir (Kadim et al., 2008). Deve eti ve diğer etlerde en fazla bulunan aa'nın ise lizin, lösin ve arginin olduğu (Kadim et al., 2008; Bekhit ve Farouk, 20l4), lizin ve metiyoninin devekușu etinden daha zengin, metiyoninin kuzu eti ile benzer olarak dana etinden düșük olduğu ifade edilmiș, esansiyel olmayan aa'lar bakımından ise deve eti dana, kuzu, oğlak ve devekușu etine benzer özellik gösterdiği belirtilmiștir (Bekhit ve Farouk, 2014).

Et kalitesi: Etin kalitesinde subjektif değerlendirme (görünüm, renk, șekil, bütünlük) ve lezzet (tat, koku) yanında gevreklik, $\mathrm{pH}$ ve su tutma kapasitesi gibi nesnel değerlendirmeler de söz konusudur. Deve eti sert, kaba, sulu, ahududu kırmızısından kahverengi kırmızıya kadar değișen renkte ve yüksek glikojen içeriğinden dolayı tatlımsıdır. Deve kası lifleri çapının hayvanın sağlık durumu, ırk, cinsiyet, yaș ve besleme durumuna göre değiștiği ve 10$100 \mu \mathrm{m}$ çapta olduğu, sığır, keçi, koyun, köpek ve atlara göre daha büyük ortalama kas lifi alanına sahip olmalarının diğer türlere göre develerin cüssesinin daha büyük olmasından kaynaklandığı belirtilmiștir (Kadim ve Mahgoub, 2014).

Etin kalite özellikleri kas yapısı, kas lifi tipi, yapı, bağ dokusu ve yașa bağlı olarak belirlenmektedir. Kas lifi tipinin deve eti kalitesi üzerine etkisinin kas lifi büyüklügünden dolayı olduğu bildirilerek, kas lifinin büyük olmasının etin daha sert olması anlamına geldiği belirtilmiștir. İkinci tip kas lifi (hızlı kasılan lif) glikojen metabolizmasıyla birinci tip kas lifinden (yavaș ve oksidatif kırmızı lif) daha büyüktür. Tip I lifleri yağca zengin ve kırmızı renktedir ve bu özelliğinden dolayı lezzet ve renk kalitesini olușturduğu bildirilirken, metabolik farklılıklarla da ilișkili olduğu ifade edilmiștir. pH, gevreklik, su tutma kapasitesi ve renk gibi deve eti kalite parametreleri kas lifi tipinden etkilenirler ve kasta $\beta$-kırmızı kas liflerine göre $\alpha$-beyaz lif oranı arttıkça bağ doku artarken, kas içi yağ ve gevreklik azalmaktadır (Kadim ve Mahgoub, 20I4).

Deve etinin dana etine göre oldukça düșük sarkoplazmik proteinlere sahip olduğu, yașın artmasıyla birlikte etin sertliğinin artmasının yanında lezzet ve kalitesinin düștüğü, optimum kalite için deve kesim yașının I-3 yaș arası olması gerektiği vurgulanmıștır (Kadim et al., 2008).

Kesim sonrasında kasların metabolizma hızı ve süresi kaslardaki glikojenin bulunmasına, depolama sıcaklığına ve metabolik reaksiyon hızına bağıı olduğu belirtilerek, kesim sonrasında ilk 24-48 saat içerisinde katı ve sert olan kaslar karkasın asılması ve bekletilmesiyle birlikte biraz yumușadığı belirtilmiștir (Kadim ve Mahgoub, 2014).

Kesim sonrasında kasın ete dönüșme süreci kasın sıcaklığı ve $\mathrm{pH}$ 'sı tarafından etkilenen fizyolojik, biyofiziksel ve biyokimyasal değișiklikleri kapsar. Kasın ete dönüșme sürecinde kas hücrelerindeki anaerobik metabolizma gereklidir ve bu süreçte kaslarda gerçekleșen glikolizis kaslardaki glikojen miktarı ve sıcaklığa bağlıdır. Hayvan kesildikten sonra kaslardaki glikojen glikoliz yoluyla parçalanarak laktik aside dönüșmesi nedeniyle kasın pH'sı düșmekte ve kasın son pH'sı et kalitesinde önemli bir kriter olarak değerlendirilmektedir. Deve eti $\mathrm{pH}$ 'sı 5.7-6.0 arasında değișirken (Kadim et al., 2008), kasın son pH'sının kesim öncesi koșullar, kesim sonrası uygulamalar, kas fizyolojisi ve kas glikojen düzeyi gibi birçok faktörden etkilendiği, son $\mathrm{pH}$ 'daki değișimin \%40-50'sinin glikojen yoğunluğu ile belirlendiği ve $\mathrm{pH}$ değerini 7.2 'den 5.5 'e düșürmek için I kg'lık kasın $0.8 \mathrm{I} \mathrm{g} / 100 \mathrm{~g}$ glikojen içermesi gerektiği belirtilmiștir (Bülbül, 20।7).

Üzerinde durulan bir diğer et kalite kriteri ise gevrekliktir. Alkali-çözülmeyen proteinler, kesme kuvveti (shear force) ve kas liflerinin çapı etin gevrekliği ile ters orantılıdır. Kesim yașı daha geç olduğu için diğer çiftlik hayvanı etlerine göre deve etinin sert, kesme kuvvetinin daha fazla, bağ doku miktarının daha yüksek olduğu söylenebilir.

Develerde yağ çoğunlukla hörgüçte depolandığından deri altı yağ tabakası daha azdır ve kesim sonrası karkasın soğuk hava deposunda hızlı soğutulmasına, soğutma sırasında daha fazla kısalan sert etler elde edilmesine neden olmaktadır (Kadim ve Mahgoub, 20I4).

Etin rengi, tüketicilerin et kalitesine ilișkin düșüncelerini etkileyen en önemli görsel özelliklerden birisidir. Et renk ölçümleri iki temel yöntemi içerir: insanların görsel değerlendirmesi ve analiz. Her iki yöntem da miyoglobin konsantrasyonunun ve kimyasal formunun, kas yapısının morfolojisinin ve kasın ıșığı absorbe etmesine ilișkin bir değerlendirmeyi içerir. Etin pigmentasyon derecesi doğrudan miyoglobin içeriğinin kimyasal yapısı ile ilgilidir. Genel olarak belirli bir kas içindeki miyoglobin konsantrasyonu türe veya yașa göre değișiklik gösterir ve kas lifi tiplerinin oranlarına bağlıdır (Bülbül, 2017). Yașlı hayvanlardan elde edilen etlerin genç hayvanların etlerine göre daha koyu (düșük L*) ve daha kırmızı (yüksek a*) olması, etin miyoglobin yoğunluğunun yüksek olmasından kaynaklanabileceği belirtilerek, kas liflerinin tipi, etin son pH'sı ve soğutma hızının da etin rengi üzerinde önemli bir etkiye sahip olduğu bildirilmiștir (Kadim et al., 2008).

Etin su tutma kapasitesi, depolama ya da buzdolabında bekletme sırasında etteki suyunun dıșarı atılmayıp ette tutunabilme kapasitesidir ve etteki minerallerin, vitaminlerin ve su hacminin kalıclığını etkiler. Su tutma kapasitesi, besin değeri, görünüm ve lezzet üzerindeki etkisi nedeniyle önemli bir et kalitesi özelliğidir. Su tutma kapasitesi, et 
proteinlerinin elektrostatik etkileri nedeniyle kas $\mathrm{pH}$ 'sından etkilenir. Deve eti, alpaka gibi diğer devegillere kıyasla, olası olarak daha düșük yağ içeriğinden dolayı yüksek miktarda açığa çıkan su içermektedir. Su kaybının miktarı kasın nihai $\mathrm{pH}$ 'sı, kas kompozisyonu ve proteinlerin dengesinin bozulması, hücre dıșı sıvının iyonik kuvveti ve lipidlerin oksidasyonu ile olușur; bu da proteinlerin çözünürlüğünü azaltır (Bülbül, 20l7). Genç hayvan etlerinin sululuğunun yașlı hayvan etlerinden daha yüksek olduğu, etin su tutma kapasitesinin yaș ve etin yağ içeriği ile birlikte azaldığı, deve etinin $40 \mathrm{dk}$ kaynatılması durumunda ağırlığının yaklașık yarısını kaybettiği belirtilmiștir (Kadim et al., 2006).

Biyoaktif bileșikler: Ette besleme açısından önemli olan birkaç biyoaktif bileșik belirlenmiștir. Bunlar metabolik aktiviteye, beslemeye ve kaslara göre değișen carnosine ( $\beta$-alanyl-I-histidine) ve türevi anserine ( $\beta$ -alanyl-I-methyl-I-histidine) memelilerin ve kanatlıların kas ve beyinlerinde yoğun olarak bulunan önemli dipeptitdirler ve beyinde antioksidanlar ve varsayılan nörotrasnmiterlar olarak ișlev görürler. Deve gluteal kası (bacak kası) taze ağırlık bazında $181.7 \mathrm{mg}$ carnosine/l00 g ve $268.6 \mathrm{mg} / \mathrm{l} 00 \mathrm{~g}$ anserine sahiptir (Bekhit ve Farouk, 20l4).

Bir diğer biyoaktif bileșik olan I-Carnitine ( $\beta$ -hydroxy- $\gamma$-trimethyl amino butyric acid) egzersiz sırasında enerji üretiminde mitokondrinin iç zarlarından uzun zincirli yağ asitlerinin tașınmasında önemli fizyolojik rol oynamaktadır. Bu biyoaktif bileșik tavuk, domuz, dana, at ve geyik etinde tespit edilmiștir. Deve etinde de taze ağırlıkta sırasıyla $5.17,2.60$ ve $7.77 \mu \mathrm{mol} / \mathrm{g}$ serbest carnitine, acylcarnitine ve toplam carnitine bulunduğu bildirilmiș ve keçi etinden sonra deve etinin I-Carnitine bakımından en zengin et olabileceği ifade edilmiștir (Bekhit ve Farouk, 20I4). Ette bulunan diğer biyoaktif bileșikler olan E Vitamini, koenzim 10, B vitamini kompleksi ve glutatyon hakkında yeterli bilginin ise mevcut olmadığı bildirilmiștir (Bekhit ve Farouk, 20l4).

\section{SONUÇ}

Dünya et üretiminde çok az bir paya sahip olmasına rağmen son yıllarda kanatlı (tavuk, ördek ve hindi) eti üretiminden sonra oransal olarak en fazla artıș deve eti üretiminde gerçekleșmiștir. Kurak-yarı kurak alanlarda sığır, koyun, keçi, manda ve domuz gibi diğer çiftlik hayvanı türlerinin yetiștirilmesinin mümkün olmamasından dolayı bu bölgelerde yașamını sürdüren deveden elde edilen süt ve et gibi ürünlerin buralarda yașayan insanların hayvansal protein açığını kapatmada oldukça önemli bir rol oynadığı da bir gerçektir. Ancak, develerde uzun gebelik süresi, düșük doğum oranı ve yüksek ilkine doğurma yașından kaynaklanan düșük döl verimi ve yavaș büyüme hızından dolayı üretilen et miktarı da sınırlıdır.

Ayrıca, karkaslarında yağ oranının düșük olmasına karșın, kemik oranının yüksek ve geç kesime gönderilmesinden dolayı diğer çiftlik hayvanı türlerine göre deve etinin daha sert olduğu söylenebilir. Özellikle genç yașta kesilmesi durumunda, deve etinin sığır eti ile benzer kalite özelliklerine sahip olacağı vurgulanmalıdır. Deve etinin kolesterol içeriğinin düșük olması ise gelecekte deve etine potansiyel bir talebin olacağının göstergesi olarak değerlendirilebilir.
Bazı ülkelerde ya da bölgelerde iklim değișikliğine bağlı yağıșların azalması ve çölleșmenin artması deve yetiștiriciliğinin her geçen gün yaygınlașmasına ve buna bağlı olarak da deve eti üretiminin artmasına katkı yapacağı söylenebilir. Ancak, deve yetiștiriciliğinin dünya genelinde çoğunlukla ekstansif koșullarda yapılması ve diğer türlere göre daha az metan gazı üretmesi bakımından deve yetiștiriciliğinin ve develerden elde edilen ve insanların beslenmesinde kullanılan deve sütü ve etinin çevre dostu bir üretim sonucunda gerçekleșmesine yol açacağı da vurgulanmalıdır.

\section{KAYNAKLAR}

Anonim (2017) Food and Agriculture Organization of the United Nations. http://www.fao.org/faostat/ (Erișim tarihi: 22.1 I.2017).

Anonim (2018) Food and Agriculture Organization of the United Nations. http://www.fao.org/faostat/ (Erișim tarihi: 25.12.2018).

Bekhit AE, Farouk MM (20I4) Nutritive and Health Value of Camel Meat. Camel Meat and Meat Products. Ed: Kadim IT, Mahgoub O, Faye B, Farouk MM. CAB International. 38 Chauncey Street Suite 1002 Bostan, MA 021 I I USA.

Bülbül A (2017) Develerde karkas ve et kalite özellikleri. Yüksek Lisans Semineri. Adnan Menderes Üniversitesi, Fen Bilimleri Enstitüsü, Zootekni Anabilim Dalı, Aydın.

Faye B (2014) Camel Meat in the World. Camel Meat and Meat Products. Ed: Kadim IT, Mahgoub O, Faye B, Farouk MM. CAB International. 38 Chauncey Street Suite 1002 Bostan, MA 021 II USA.

İnce K, Önal ME (2017) Deve yetiștiriciliği ve devecilik kültürü. Lisans Bitirme Tezi. Adnan Menderes Üniversitesi, Ziraat Fakültesi, Zootekni Bölümü, Aydın.

Kadim IT, Farouk MM, Mahgoub O, Bekhit AE (20I4) Slaughtering and Processing of Camels. Camel Meat and Meat Products. Ed: Kadim IT, Mahgoub O, Faye B, Farouk MM. CAB International. 38 Chauncey Street Suite 1002 Bostan, MA 02I II USA.

Kadim IT, Mahgoub O (2014) Camel Body Growth. Camel Meat and Meat Products. Ed: Kadim IT, Mahgoub O, Faye B, Farouk MM. CAB International. 38 Chauncey Street Suite 1002 Bostan, USA.

Kadim IT, Mahgoub O, Al-Marzooqi W, Al-Zadgali S, Annamali K, Mansour MH (2006) Effects of age on composition and quality of muscle Longissimus thoracis of the Omani Arabian camel (Camelus dromedarius). Meat Science 73: 619-625.

Kadim IT, Mahgoub O, Purchas RW (2008) A review of the growth, and of the carcass and meat quality characteristics of the one-humped camel (Camelus dromedarius). Meat Science 80: 555-569.

Swatland HJ (2014) Prospects for Online Grading of Camel Meat Yield and Quality. Camel Meat and Meat Products. Ed: Kadim IT, Mahgoub O, Faye B, Farouk MM. CAB International. 38 Chauncey Street Suite 1002 Bostan, MA 02 I I I USA. 